\title{
Vitamin D deficiency is related to thyroid antibodies among type 2 diabetic mellitus patients
}

\author{
Khalid S Aljabri ${ }^{*}$, Ibrahim M Alnasser ${ }^{2}$, Samia A Bokhari ${ }^{1}$, Muneera A Alshareef ${ }^{1}$, Patan M Khan ${ }^{1}$, Abdulla M Mallisho', Hesham M \\ AbuElsaoud ${ }^{1}$, Mohammad M Jalal', Rania F Safwat ${ }^{1}$, Rehab El Boraie ${ }^{1}$, Abdullah A Alamri ${ }^{1}$, Bushra A Baeshen ${ }^{1}$, Waleed O Bawzeer ${ }^{1}$, \\ Mohammad A Melibari ${ }^{1}$, Nawaf KAljabri ${ }^{3}$, Bandari KAljabri ${ }^{4}$ and Turky A Alharthy ${ }^{5}$
}

${ }^{1}$ Department of Endocrinology, King Fahad Armed Forces Hospital, Jeddah, Kingdom of Saudi Arabia

${ }^{2}$ Department of Radiology, King Fahad Armed Forces Hospital, Jeddah, Kingdom of Saudi Arabia

${ }^{3}$ Department of Laboratory, King Fahad Armed Forces Hospital, Jeddah, Kingdom of Saudi Arabia

${ }^{4}$ Faculty of Medicine, Um Al Qura University, Makkah, Kingdom of Saudi Arabia

${ }^{5}$ College of Medicine, Jeddah, Kingdom of Saudi Arabia

\begin{abstract}
Introduction: Very few studies in the past have reported on an association between thyroid autoimmunity and 25-hydroxyvitamin D (25-OHD), and these have produced inconclusive results. Therefore, in the present study, we examined the relationship between thyroid antibodies and vitamin $\mathrm{D}$ status among patients with type 2 diabetes mellitus (T2DM).

Method: A cross-sectional single centre study was conducted in 4053 patients with T2DM. Patients with T2DM attended the Diabetes Centre at King Fahad Armed Forces Hospital, Jeddah, Saudi Arabia between January 2018 and December 2018 were recruited. The serum concentration of 25-OHD, HbA1c, thyroid stimulating hormone (TSH), free thyroxine (FT4), HbA1c, anti-thyroid peroxidase (anti-TPO) and anti-thyroglobulin (anti-TG) were measured.

Results: A total of 193 participants were included in this study. Average age of the study population was $46.4 \pm 14.9$ years. There was $47.7 \%$ with VDD. The concentration of anti-TPO and anti-TG antibodies were statistically significant higher in patients with VDD than in those with higher vitamin D levels $(p=0.04$ and $p=0.03$ respectively). The presence of anti-TPO and anti-TG antibodies were statistically non-significant more common in patients with vitamin D deficiency than in those with higher vitamin D levels. However, the mean serum 25-OHD level were statistically non-significant lower in patients with anti-TPO and anti-TG antibodies positive groups than in those with below cut off titers. Only age was found to be an independent predictor of serum $25-\mathrm{OHD}$ levels $(p=0.04)$. Serum $25-\mathrm{OHD}$ levels was found to be an independent predictor of serum anti-TPO levels $(p=0.03)$. Gender was found to be an independent predictor of serum anti-TG levels $(p=0.04)$.
\end{abstract}

Conclusion: It remains unclear whether VDD contributes to the pathogenesis of AITDs or is a consequence of the diseases. Since we found statistically nonsignificant inverse correlation between vitamin D levels and thyroid antibody levels, we might speculate that there might exist a casual relationship if the sample size was sufficiently large enough to reveal a significant correlation.

\section{Introduction}

Vitamin D is recognized to be an essential element for bone metabolism and skeletal health [1]. In addition, it may also affect extraskeletal health. The recent description that many tissues and cells in the body express the vitamin $\mathrm{D}$ receptor resulted in a growing interest in the role of vitamin $\mathrm{D}$ in extra-skeletal conditions such as autoimmune diseases [2-5]. Vitamin D is a potent immunomodulator. Most immune cells, including macrophages, antigen-presenting cells, lymphocytes $\mathrm{T}$ and $\mathrm{B}$, express not only VDR $[6,7]$. Not only vitamin D status, but also polymorphism of genes involved in vitamin $\mathrm{D}$ metabolism, transport and activity was shown to be associated to susceptibility to autoimmune disorders [7]. In spite of the advancements in understanding the pathophysiologic mechanisms of autoimmune thyroid diseases (AITD), its primary underlying cause remains elusive $[8,9]$. The majority of investigators agree that AITD is a multifactorial disease in which autoimmune attack on the thyroid plays a fundamental role through infiltration of the gland by T- and B-cells and production of specific autoantibodies reactive to thyroid antigens, such as thyroid peroxidase (TPO) and thyroglobulin (TG).
Vitamin D deficiency (VDD) remains a major health problem in many parts of the world [10]. VDD has received special attention lately because of its high incidence and its implication in the genesis of multiple chronic illnesses. The high prevalence of VDD in general population underlines the fact that VDD is more common in chronic diseases like diabetes mellitus.

Type 2 diabetes mellitus (T2DM) and hypothyroidism are the main threats in developed and developing countries and impairs the health and economic status $[11,12]$. T2DM increases the risk of thyroid dysfunction in the long-term [13-19]. T2DM and thyroid dysfunction are the primary reasons for mortality and morbidity in most high

${ }^{\star}$ Correspondence to: Khalid S. Aljabri, Department of Endocrinology, King Fahad Armed Forces Hospital, Jeddah, Kingdom of Saudi Arabia, E-mail: khalidsaljabri@yahoo.com

Key words: type 2 diabetes mellitus, thyroid antibodies and vitamin D deficiency Received: April 16, 2019; Accepted: July 18, 2019; Published: July 22, 2019 
income and developing countries [15-19]. However, several studies have shown a higher prevalence of thyroid dysfunction occurring among T2DM patients [17-22]. Moreover, positive correlations between VDD and thyroid dysfunction among T2DM patients have been reported by several authors [1,21-24].

Very few studies in the past have reported on a putative association between thyroid autoimmunity and 25-hydroxyvitamin D (25-OHD), and these have produced inconclusive results [21,22,24-27]. Therefore, in the present study, we examined the relationship between thyroid antibodies and vitamin D status among patients with T2DM.

\section{Methods}

A cross-sectional single centre study was conducted in 2019 patients with T2DM attended the Diabetes Centre at King Fahad Armed Forces Hospital, Jeddah, Saudi Arabia between January 2018 and December 2018. Eligible patients were 20 years or older. Exclusion criteria were known hepatic or renal disease, metabolic bone disease, malabsorption, hypercortisolism, pregnancy and medications influencing bone metabolism. The serum concentration of 25-OHD was measured by competitive protein binding assay using kits (Immunodiagnostic, Bensheim, Germany). VDD was defined as serum 25-OHD concentration < $50 \mathrm{nmol} / \mathrm{L} \mathrm{[1]}$. Glycosylated hemoglobin (HbAlc) was measured by the high-performance liquid chromatography method (Bio-Rad Laboratories, Waters, MA, USA). Thyroid stimulating hormone (TSH), anti-TPO, and anti-TG were measured with a chemiluminescent immunoassay method (CMIA) (Architect i2000 system, Abbott, USA). Serum free thyroxine (FT4) was estimated by radioimmunoassay. The assays have intra- assay precision of $4.3 \%, 5.8 \%$, and $3.2 \%$, respectively. Positive anti-TPO, and anti-TG were defined as a value greater than $5.6 \mathrm{IU} / \mathrm{ml}$ and $4.1 \mathrm{IU} / \mathrm{ml}$, respectively. TSH levels between 0.22-4.2 mIU/L and Free T4 12.0-22.0 $\mathrm{pmol} / \mathrm{L}$ were regarded normal [28]. The study was approved by the ethical committee board of King Fahad Armed Forces Hospital.

\section{Statistical analysis}

Data are presented as means \pm standard deviation (SD) or numbers (\%). Quantitative variables were compared between two groups by using the Student's test. Differences in categorical variables were analyzed using the chi-square test. The relationship between continuous variables was assessed using coefficients of correlation. Linear regression analyses were performed to examine the factors that predicted serum concentrations of $25(\mathrm{OH}) \mathrm{D}$, anti-TPO, and anti-TG. Multivariate linear regression model was constructed using serum $25(\mathrm{OH}) \mathrm{D}$, antiTPO and anti-TG as the dependent variables and factors with either a $P$-value less than 0.15 in the univariate analysis or a previously reported association with either 25-OHD, anti-TPO or anti-TG as independent variables. Null hypotheses were rejected where $\mathrm{p}$ values were less than 0.05 . Logistic regression analysis was carried out to estimate odds ratio $(\mathrm{OR})$ and $95 \%$ CI. $P$ value $<0.05$ indicates significance. The statistical analysis was conducted with SPSS version 23.0 for Windows.

\section{Results}

A total of 193 participants were included in this study. Average age of the study population was $46.4 \pm 14.9$ years (Table 1 ). There was $47.7 \%$ with VDD. Patients with VDD were younger (mean age: 44 years versus 49 years; $p=0.04$ ) and included statistically non-significant more females ( $79 \%$ versus $27 \% ; p=0.2$ ). The levels of anti-TPO and anti-TG antibodies were statistically significant higher in patients with VDD than in those with higher vitamin D levels ( $p=0.04$ and $p=0.03$ respectively).
The presence of anti-TPO and anti-TG antibodies were statistically non-significant more common in patients with vitamin $\mathrm{D}$ deficiency than in those with higher vitamin D levels (Figure 1A and 1B). However, the mean serum 25-OHD level were statistically non-significant lower in patients with anti-TPO and anti-TG antibodies positive groups than in those with below cut off titers (Figure 2A and 2B).

In order to identify the independent factors affecting 25-OHD levels, a multivariate linear regression model was constructed using the serum 25-OHD concentrations as the dependent factor. The constructed model is shown in table 2. Age, gender, $\mathrm{HbA1c}$, TSH, antiTPO and anti-TG antibodies were the independent predictors of 25OHD levels. In the constructed model, only age was found to be an independent predictor of serum 25-OHD levels $(p=0.04)$ (Table 2).

The second linear regression model using serum anti-TPO levels as the dependent variable was performed with age, gender, TSH and $25-\mathrm{OHD}$ levels as independent variables (Table 3 ). In the constructed model, serum 25-OHD levels was found to be an independent predictor of serum anti-TPO levels $(p=0.03)$.

The third linear regression analysis using serum anti-TG levels as the dependent variable was performed with age, gender, TSH and 25-OHD levels as independent variables (Table 4). In the constructed

Table 1. Distribution of patients based on vitamin D deficiency categories [mean \pm standard deviation or number $(\%)]$

\begin{tabular}{|c|c|c|c|c|c|}
\hline \multirow{2}{*}{\multicolumn{2}{|c|}{ Variable }} & \multirow{2}{*}{ Total } & \multicolumn{2}{|c|}{ Vitamin D deficiency } & \multirow{3}{*}{$P$ values } \\
\hline & & & Present & Absent & \\
\hline \multicolumn{2}{|c|}{ Numbers } & 193 & $92(47.7)$ & $101(52.3)$ & \\
\hline \multicolumn{2}{|c|}{ Age (years) } & $46.4 \pm 14.9$ & $44.1 \pm 13.9$ & $48.5 \pm 15.6$ & 0.04 \\
\hline \multirow{2}{*}{ Gender } & Male & $34(17.6)$ & $19(27.0)$ & $15(14.9)$ & \multirow{2}{*}{0.2} \\
\hline & Female & $159(82.4)$ & $73(79.3)$ & $86(85.1)$ & \\
\hline \multicolumn{2}{|c|}{ HbAlc (\%) } & $6.8 \pm 2.0$ & $7.1 \pm 2.1$ & $6.6 \pm 2.0$ & 0.3 \\
\hline \multicolumn{2}{|c|}{$\begin{array}{l}\text { 25-hydroxyvitamin D } \\
(\mathrm{nmol} / \mathrm{L})\end{array}$} & $62.6 \pm 38.7$ & $34.3 \pm 9.6$ & $88.4 \pm 37.3$ & $<0.0001$ \\
\hline \multicolumn{2}{|c|}{ TSH (mIU/l) } & $4.1 \pm 7.7$ & $4.1 \pm 6.6$ & $4.1 \pm 8.6$ & 0.9 \\
\hline \multicolumn{2}{|c|}{ FT4 (IU/ml) } & $15.7 \pm 5.0$ & $15.3 \pm 4.6$ & $16.1 \pm 5.3$ & 0.2 \\
\hline \multicolumn{2}{|c|}{ Anti-TPO (IU/ml) } & $101.0 \pm 170.4$ & $142.1 \pm 216.4$ & $61.0 \pm 95.9$ & 0.04 \\
\hline \multicolumn{2}{|c|}{ Anti-TG (IU/ml) } & $68.9 \pm 206.8$ & $103.0 \pm 281.4$ & $37.0 \pm 83.5$ & 0.03 \\
\hline
\end{tabular}

Table 2. Linear regression analysis using serum 25-hydroxyvitamin D concentrations as the dependent variable

\begin{tabular}{|c|c|c|c|c|}
\hline Parameters & Coefficients & Std. Error & $\begin{array}{c}\mathbf{9 5 \%} \\
\text { Confidence } \\
\text { interval }\end{array}$ & P value \\
\hline Age (years) & 0.666 & 0.307 & $0.036-1.295$ & 0.04 \\
\hline Gender & -16.534 & 16.217 & $-49.808-16.740$ & 0.5 \\
\hline HbA1c (\%) & -2.642 & 2.435 & $7.637-2.354$ & 0.3 \\
\hline TSH (mIU/l) & -2.251 & 2.088 & $-6.806-1.764$ & 0.2 \\
\hline FT4 (mIU/l) & 3.737 & 2.488 & $-1.367-8.841$ & 0.1 \\
\hline Anti-TPO (IU/ml) & -0.006 & 0.045 & $-0.099-0.087$ & 0.9 \\
\hline Anti-TG (IU/ml) & 0.002 & 0.018 & $-0.035-0.038$ & 0.9 \\
\hline
\end{tabular}

Table 3. Linear regression analysis using serum concentrations of Anti-TPO as the dependent variable.

\begin{tabular}{|c|c|c|c|c|}
\hline Parameters & Coefficients & Std. Error & $\begin{array}{c}\mathbf{9 5 \%} \\
\text { Confidence } \\
\text { interval }\end{array}$ & P value \\
\hline Age (years) & 1.715 & 1.213 & $-0.706-4.135$ & 0.2 \\
\hline Gender & 32.252 & 54.766 & $\begin{array}{c}-77.062- \\
141.566\end{array}$ & 0.6 \\
\hline TSH (mIU/l) & -3.328 & 7.601 & $-18.500-11.843$ & 0.7 \\
\hline $\begin{array}{c}\text { 25-hydroxyvitamin D } \\
\text { (nmol/L) }\end{array}$ & -1.594 & 0.722 & $-3.036-(-0.152)$ & 0.03 \\
\hline
\end{tabular}


Table 4. Linear regression analysis using serum concentrations of Anti-TG as the dependent variable

\begin{tabular}{|c|c|c|c|c|}
\hline Parameters & Coefficients & Std. Error & $\begin{array}{c}\mathbf{9 5 \%} \\
\text { Confidence } \\
\text { interval }\end{array}$ & P value \\
\hline Age (years) & -1.832 & 1.005 & $-3.818-0.153$ & 0.07 \\
\hline Gender & -81.214 & 38.395 & $\begin{array}{c}-157.022- \\
(-5.406)\end{array}$ & 0.04 \\
\hline TSH (mIU/l) & 0.953 & 1.896 & $-2.791-4.697$ & 0.6 \\
\hline $\begin{array}{c}\text { 25-hydroxyvitamin } \\
\text { D (nmol/L) }\end{array}$ & -0.260 & 0.432 & $-1.113-0.593$ & 0.5 \\
\hline
\end{tabular}

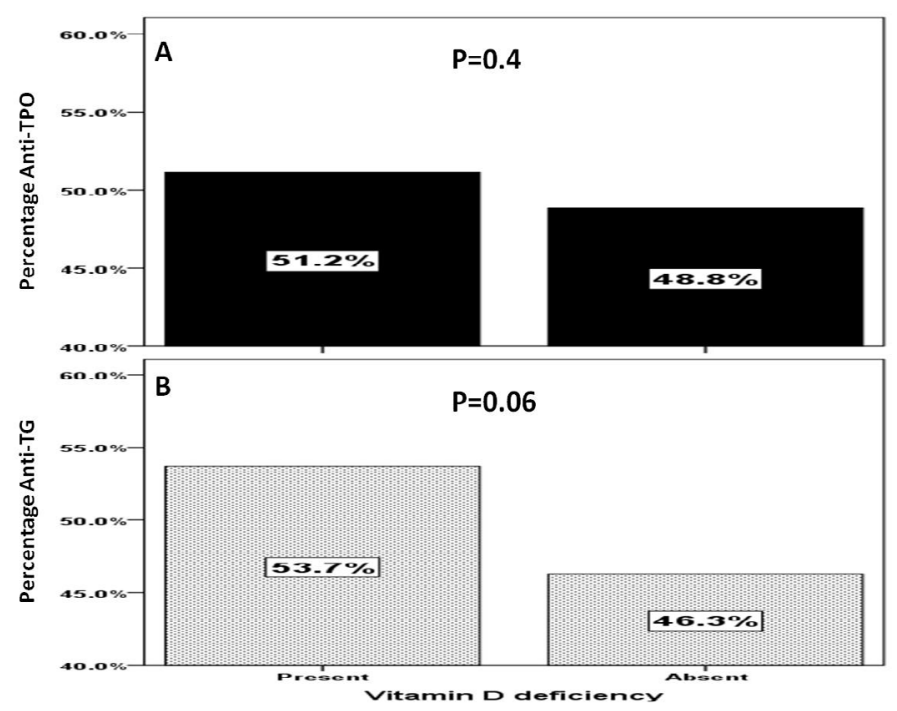

Figure 1. Percentage of Anti-TPO (A) and Anti-TG (B) levels in patients with and without vitamin $\mathrm{D}$ deficiency
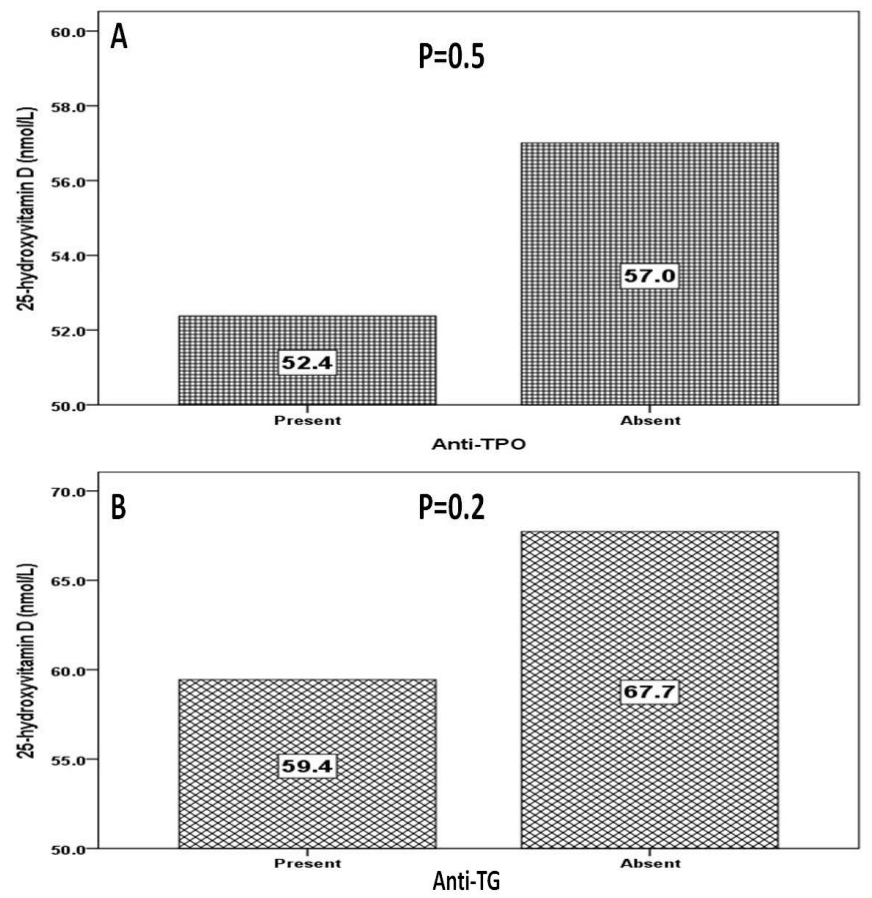

Figure 2. Mean 25-hydroxyvitamin (nmol/l) D level in patients with and without Anti-TPO (A) and Anti-TG (B) model, gender was found to be an independent predictor of serum antiTG levels $(p=0.04)$.

\section{Discussion}

T2DM is currently the most prevalent chronic illness in the world having a prevalence of around $9 \%$ in the adult population and $30 \%$ of Saudi adults $[29,30]$. Thyroid diseases are among the most common endocrine abnormalities, and AITDs are perhaps the most prevalent autoimmune diseases [31,32]. Our study demonstrated statistically non-significant negative association between 25-OHD levels and TPO levels and have also shown that the low 25-OHD level is a possible risk factor of TPO positivity but not Anti-TG levels. To our best knowledge, this is the first study that evaluate the association between thyroid autoantibodies and vitamin D levels in Saudi patients with T2DM. VDD and T2DM are usually recognized as a complication and risk for thyroid disease. VDD has received special attention because of its high incidence and its implication in the genesis of multiple chronic illnesses. AITD are relatively common organ-specific autoimmune disorders that cause diseases ranging in severity from hypothyroidism to hyperthyroidism. ${ }^{33}$ As an immune modulator, vitamin D is involved in the onset and development of AITD [24,34] Inspired by studies on the relationship of vitamin $\mathrm{D}$ and other autoimmune diseases, researchers have been focusing on the link between vitamin D and AITD in recent years. Low levels of vitamin D have been demonstrated in patients with AITD defined as elevated antithyroid antibodies with or without characteristic ultrasonographic features (diffuse parenchymal hypoechogenicity and/or heterogeneous echogenic pattern of thyroid gland) [24,25,34-37]. Furthermore, VDD was correlated with antithyroid antibodies levels [34]. In 1990, an animal study first demonstrated that 25-OHD administration could prevent the induction of experimental autoimmune thyroiditis [38]. The effects of various environmental factors and the intrinsic genetic predisposition of an individual may contribute to the initiation of AITDs. In pathological conditions like thyroiditis, infiltrating lymphocytes, Fas-mediated apoptosis and cytokines released from both immune cells and thyrocytes contribute to amplification and progression of AITD [39-44]. According to this theory, as a result of defective suppressor T cells, Th (CD4) cells are able to activate and cooperate with B lymphocytes. B lymphocytes activated by $\mathrm{T}$ lymphocytes produce antibodies that react with thyroid antigens.

We found that the levels of anti-TPO and anti-TG antibodies were statistically significant higher in patients with VDD than in those with higher vitamin $\mathrm{D}$ levels ( $p=0.04$ and $p=0.03$ respectively). Many authors observed that subjects with low 25-OHD levels had more frequently elevated anti-TPO antibodies and/or anti-TG antibodies [21,24,25,34-37,45]. In addition, in subjects with AITD, statistically non-significant negative correlation between 25-OHD, anti-TPO and anti-TG antibodies $(r=-0.214, p=0.07$ and $r=-0.114, p=0.1)$ [46]. The relationship between low 25-OHD levels and the presence of antiTPO and anti-TG antibodies was not always observed [35,36,45,47]. Goswami et al. in a group of 642 subjects from India revealed no association between VDD 25-OHD $<25 \mathrm{nmol} / \mathrm{l}$ ) and anti-TPO positivity [25]. The correlation of 25-OHD levels with AITD was initially confirmed by Kivity's group in 2011, in which they found that the presence of antithyroid antibodies and abnormal thyroid functions was more prevalent in subjects with VDD [24]. In the study of Yasmeh et al. the mean 25-OHD levels were not significantly different in AITD males and healthy controls ( $36 \mathrm{vs.} 33 \mathrm{nmol} / \mathrm{l}$ ) and were even higher in females with AITD than in healthy ones ( $77 \mathrm{vs} .69 \mathrm{nmol} / \mathrm{l})$. AITD females were 
more often vitamin D sufficient (51.7 vs. $31.1 \%$ ) than control females. Furthermore, in males, a significant positive correlation between 25OHD and anti-TPO antibodies was observed $(r=0.436, p=0.016)$ [48]. The authors concluded that AITD is not associated with higher prevalence of VDD. In an elderly population with a high prevalence of VDD /insufficiency patients with T2DM were found to be 2.5 times more likely to have AITD compared to a non-diabetic individual, but, interestingly, the higher the serum 25-OHD levels were, the higher this chance was [49]. In women with polycystic ovary syndrome, 25OHD levels were significantly lower in subjects with AITD than in those without AITD $(p=0.02)$ [50]. In the study of Mazokopakis et al. including 218 hypothyroidism patients, there was a significant negative correlation only between serum 25-OHD and anti-TPO concentrations and anti-TPO levels were significantly higher in 186 vitamin D deficient subjects compared to those with no VDD $(364 \pm 181 \mathrm{IU} / \mathrm{ml}$ vs. $115.8 \pm$ $37.1 \mathrm{IU} / \mathrm{ml}, p<0.0001$ ) [35]. Bozkurt et al. found serum 25-OHD was inversely correlated with anti-TPO $(\mathrm{r}=-0.361, p<0.001)$ and anti-TG levels $(r=-0.335, p<0.001)$ [21]. In a study on Egyptian children, there were significant negative correlations between serum 25-OHD and age, anti-TPO, anti-TG and TSH ( $p<0.001$ each) [51]. Although available data remain controversial, vitamin $\mathrm{D}$ has shown to be a new developing issue in the pathogenesis of AITD. The lack of the association between serum 25-OHD levels and TPO titers in some studies may have been because the sample size was not sufficiently large enough to reveal a strong correlation.

This study has not shown a difference in vitamin D level related to thyroid function. This suggests that VDD is more closely related to anti-thyroid antibody titer rather than thyroid function itself in humans, and also agrees with the existing study on patients with Hashimoto's thyroiditis [26]. We suggest that vitamin D functions as an immune modulator in autoimmune thyroiditis and that the molecular mechanism should be further investigated to clarify the causal relationship between 25-OHD level and autoimmune thyroiditis. It is notable that a significant negative association between anti-TPO levels and 25-OHD level. This may be due to an overall low vitamin D level and high prevalence of AITD in the Saudi population. In fact, the correlation between 25-OHD level and anti-TPO levels is also seen in vitamin $\mathrm{D}$ level within the range of vitamin $\mathrm{D}$ deficiency as defined by a recent guideline on bone metabolism, suggesting a need of a different reference value of vitamin $\mathrm{D}$ for this extra-skeletal effect.

We had some limitations. study was done at only one centre and was done at one point of time. The study sample confined to patients with T2DM and VDD but without comparable groups.

\section{Conclusion}

The majority of the studies have reported an association between low vitamin D status and increased risk of thyroid autoimmunity. It remains unclear whether vitamin $\mathrm{D}$ deficiency contributes to the pathogenesis of AITDs or is a consequence of the diseases. Since we found statistically non-significant inverse correlation between vitamin $\mathrm{D}$ levels and thyroid antibody levels, we might speculate that there might exist a casual relationship if the sample size was sufficiently large enough to reveal a significant correlation.

\section{Acknowledgment}

There is no financial support or relationships that may pose conflict of interest.

\section{References}

1. Holick MF (2007) Vitamin D deficiency. N Engl J Med 357: 266-281. [Crossref]

2. Vanoirbeek E, Krishnan A, Eelen G, Verlinden L, Bouillon R, et al. (2011) The anticancer and anti-inflammatory actions of 1,25(OH)2D3. Best Pract Res Clin Endocrinol Metab 25: 593-604. [Crossref]

3. Woloszynska-Read A, Johnson CS, Trump DL (2011) Vitamin D and cancer: clinical aspects. Best Pract Res Clin Endocrinol Metab 25: 605-615. [Crossref]

4. Leu M, Giovannucci E (2011) Vitamin D: epidemiology of cardiovascular risks and events. Best Pract Res Clin Endocrinol Metab 25: 633-646.

5. Van Belle TL, Gysemans C \& Mathieu C (2011) Vitamin D in autoimmune, infectious and allergic diseases: a vital player? Best Pract Res Clin Endocrinol Metab 25: 617632. [Crossref]

6. Makariou S, Liberopoulos EN, Elisaf M, Challa A (2011) Novel roles of vitamin D in disease: what is new in 2011? Eur J Intern Med 22: 355-362. [Crossref]

7. Bizzaro G, Antico A, Fortunato A, Bizzaro N (2017) Vitamin D and Autoimmune Diseases: Is Vitamin D Receptor (VDR) Polymorphism the Culprit? Isr Med Assoc J 19: 438-443. [Crossref]

8. Marinò M, Latrofa F, Menconi F, Chiovato L, Vitti P (2014) Role of genetic and nongenetic factors in the etiology of Graves' disease. J Endocrinol Invest 38: 283-294. [Crossref]

9. D'Aurizio F, Villalta D, Metus P, Doretto P, Tozzoli R (2015) Is vitamin D a playe or not in the pathophysiology of autoimmune thyroid diseases? Autoimmun Rev 14: 363-369. [Crossref]

10. Holick MF (2006) High prevalence of vitaminD inadequacy and implications for health. Mayo Clin Proc 81: 353-373. [Crossref]

11. Alberti KG, Eckel RH, Grundy SM, Zimmet PZ, Cleeman JI, et al. (2009) Harmonizing the metabolic syndrome: a joint interim statement of the International Diabetes Federation Task Force on Epidemiology and Prevention; National Heart, Lung, and Blood Institute; American Heart Association; World Heart Federation; International Atherosclerosis Society; and International Association for the Study of Obesity. Circulation 120: 1640-1645. [Crossref]

12. Bener A, Zirie M, Musallam M, Khader YS, Al-Hamaq AO (2009) Prevalence of metabolic syndrome according to Adult Treatment Panel III and International Diabetes Federation criteria: a population-based study. Metab Syndr Relat Disord 7: 221-229. [Crossref]

13. Bener A, Al-Hamaq AO, Kurtulus EM, Abdullatef WK, Zirie M (2016) The role of vitamin D, obesity and physical exercise in regulation of glycemia in Type 2 Diabetes Mellitus patients. Diabetes Metab Syndr 10: 198-204. [Crossref]

14. Al-Wazzan HT, Daban AH, Askar RA. El-Shazly MK (2010) Prevalence and associated factors of thyroid dysfunction among type 2 diabetic patients in Kuwait. Alex Bull 46: 141-148.

15. Papazafiropoulou A, Sotiropoulos A, Kokolaki A, Kardara M, Stamataki P, et al. (2010) Prevalence of thyroid dysfunction among greek type 2 diabetic patients attending an outpatient clinic. J Clin Med Res 2: 75-78. [Crossref]

16. Akbar DH, Ahmed MM, Al-Mughales J (2006) Thyroid dysfunction and thyroid autoimmunity in Saudi type 2 diabetics. Acta Diabetol 43: 14-18. [Crossref]

17. Bener A, Ozdenkaya Y, Barişik CC, Ozturk M (2018) The impact of metabolic syndrome on increased risk of thyroid nodules and size. Health Service Res Man Epidemiology 5:1-6.

18. Sarfo-Kantanka O, Sarfo FS, Ansah EO, Yorke E, Akpalu J, et al. (2017) Frequency and determinants of thyroid autoimmunity in Ghanaian type 2 diabetes patients: a casecontrol study. BMC Endocr Disord 17: 2. [Crossref]

19. Centeno Maxzud M, Gomez Rasjido L, Fregenal M, Arias Calafiore F, Cordoba Lanus M, et al. (2016) [Prevalence of thyroid dysfunction in patients with type 2 diabetes mellitus]. Medicina (B Aires) 76: 355- 358. [Crossref]

20. Van Belle TL, Gysemans C, Mathieu C (2013) Vitamin D and diabetes: the odd couple. Trends Endocrinol Metab 24: 561-568. [Crossref]

21. Bozkurt NC, Karbek B, Ucan B, Sahin M, Cakal E, et al. (2013) The association between severity of vitamin D deficiency and Hashimoto's thyroiditis. Endocr Pract 19: 479-484. [Crossref]

22. Kim D (2016) Low vitamin D status is associated with hypothyroid Hashimoto's thyroiditis. Hormones (Athens) 15: 385-393. [Crossref] 
23. Mazokopakis EE, Kotsiris DA (2014) Hashimoto's autoimmune thyroiditis and vitamin D deficiency. Current aspects. Hell J Nucl Med 17: 37-40. [Crossref]

24. Kivity S, Agmon-Levin N, Zisappl M, Shapira Y, Nagy EV, et al. (2011) Vitamin D and autoimmune thyroid diseases. Cell Mol Immunol 8: 243-247. [Crossref]

25. Goswami R, Marwaha RK, Gupta N, Tandon N, Sreenivas V, et al. (2009) Prevalence of vitamin Ddeficiency and its relationship with thyroid autoimmunity in Asian Indians: a community-based survey. British Journal of Nutrition 102: 382-386. [Crossref]

26. Tamer G, Arik S, Tamer I, Coksert D (2011) Relative vitamin D insufficiency in Hashimoto's thyroiditis. Thyroid 21: 891-896. [Crossref]

27. Kmieć P, Sworczak K (2015) Vitamin D in thyroid disorders. Exp Clin Endocrinol Diabetes 123: 386-393. [Crossref]

28. Jun JE, Jee JH, Bae JC, Jin SM, Hur KY, et al. (2016) Association between changes in thyroid hormones and incident type 2 diabetes: A seven-year longitudinal study. Thyroid 27: 29-38. [Crossref]

29. Alqurashi KA, Aljabri KS, Bokhari SA (2011) Prevalence of diabetes mellitus in a Saudi community. Ann Saudi Med 31: 19-23. [Crossref]

30. World Health Organization [Internet]. Global status report on non-communicable diseases 2014. Available at: http://www.who.int/nmh/ publications/ncd-statusreport-2014/en

31. Shapira Y, Agmon-Levin N, Shoenfeld Y (2010) Geoepidemiology of autoimmune diseases. Autoimmunity 8: 468-476. [Crossref]

32. Shoenfeld Y, Selmi C, Zimlichman E, Gershwin ME (2008) The autoimmunologist: geoepidemiology, a new center of gravity, and prime time for autoimmunity. $J$ Autoimmun 31: 325-330. [Crossref]

33. Hollowell JG, Staehling NW, Flanders WD, Hannon WH, Gunter EW, et al. (2002) Serum TSH, T(4), and thyroid antibodies in the United States population (1988 to 1994): National Health and Nutrition Examination Survey (NHANES III). J Clin Endocrinol Metab 87: 489-499. [Crossref]

34. Bizzaro G and Shoenfeld Y (2015) Vitamin D and autoimmune thyroid diseases: facts and unresolved questions. Immunol Res 61: 46-52. [Crossref]

35. Mazokopakis EE, Papadomanolaki MG, Tsekouras KC, Evangelopoulos AD, Kotsiris DA, et al. (2015) Is vitamin D related to pathogenesis and treatment of Hashimoto's thyroiditis? Hell J Nucl Med 18: 222-227. [Crossref]

36. Ma J, Wu D, Li C, Fan C, Chao N, et al. (2015) Lower Serum 25-Hydroxyvitamin D Level is Associated With 3 Types of Autoimmune Thyroid Diseases. Medicine (Baltimore) 94: e1639. [Crossref]

37. Choi YM, Kim WG, Kim TY, Bae SJ, Kim HK, et al. (2014) Low levels of serum vitamin D3 are associated with autoimmune thyroid disease in pre-menopausal women. Thyroid 24: 655-661. [Crossref]
38. Abe J, Nakamura K, Takita Y, Nakano T, Irie H, et al. (1990) Prevention of immunological disorders in MRL/1 mice by a new synthetic analogue of vitamin D3: 22-oxa-1 alpha,25-dihydroxyvitamin D3. J Nutr Sci Vitaminol (Tokyo) 36: 21-31. [Crossref]

39. Ng HP, Banga JP, Kung AW (2004) Development of a murine model of autoimmune thyroiditis induced with homologous mouse thyroid peroxidase. Endocrinology 145 : 809-816. [Crossref]

40. McLachlan SM, Nagayama Y, Rapoport B (2005) Insight into Graves' hyperthyroidism from animal models. Endocr Rev 26: 800-832. [Crossref]

41. Many MC, Maniratunga S, Varis I, Dardenne M, Drexhage HA, et al. (1995) Two-step development of Hashimoto-like thyroiditis in genetically autoimmune prone non-obese diabetic mice: effects of iodine-induced cell necrosis. J Endocrinol 147: 311-320. [Crossref]

42. Caturegli P, Hejazi M, Suzuki K, Dohan O, Carrasco N, et al. (2000) Hypothyroidism in transgenic mice expressing IFN-gamma in the thyroid. Proc Natl Acad Sci U S A 97 1719-1724. [Crossref]

43. Kimura H, Kimura M, Tzou SC, Chen YC, Suzuki K, et al. (2005) Expression of class Il major histocompatibility complex molecules on thyrocytes does not cause spontaneous thyroiditis but mildly increases its severity after immunization. Endocrinology 146 1154-1162. [Crossref]

44. Nagayama Y (2005) Animal models of Graves' hyperthyroidism. Endocr J 52: 385 394. [Crossref]

45. Wang X, Zynat J, Guo Y, Osiman R, Tuhuti A, et al. (2015) Low Serum Vitamin D Is Associated with Anti-Thyroid-Globulin Antibody in Female Individuals. Int $J$ Endocrinol 2015: 285-290. [Crossref]

46. Muscogiuri G, Mari D, Prolo S, Fatti LM, Cantone MC, et al. (2016) 25 Hydroxyvitamin D Deficiency and Its Relationship to Autoimmune Thyroid Disease in the Elderly. Int $J$ Environ Res Public Health 13: 850. [Crossref]

47. Chailurkit LO, Aekplakorn W, Ongphiphadhanakul B (2013) High vitamin D status in younger individuals is associated with low circulating thyrotropin. Thyroid 23: 25-30. [Crossref]

48. Yasmeh J, Farpour F, Rizzo V, Kheradnam S, Sachmechi I (2016) HASHIMOTO THYROIDITIS NOT ASSOCIATED WITH VITAMIN D DEFICIENCY. Endocr Pract 22: 809-813. [Crossref]

49. Toulis K, Tsekmekidou X, Potolidis E, Didangelos T, Gotzamani-Psarrakou A, et al (2015) Thyroid Autoimmunity in the Context of Type 2 Diabetes Mellitus: Implications for Vitamin D. Int J Endocrinol 2015: 710363. [Crossref]

50. Muscogiuri G, Palomba S, Caggiano M, Tafuri D, Colao A, et al. (2016) Low $25(\mathrm{OH})$ vitamin D levels are associated with autoimmune thyroid disease in polycystic ovary syndrome. Endocrine 53: 538-542. [Crossref]

51. Metwalley KA, Farghaly HS, Sherief T, Hussein A (2016) Vitamin D status in children and adolescents with autoimmune thyroiditis. J Endocrinol Inves 39: 793-797. [Crossref]

Copyright: @2019 Aljabri KS. This is an open-access article distributed under the terms of the Creative Commons Attribution License, which permits unrestricted use, distribution, and reproduction in any medium, provided the original author and source are credited. 